\title{
The Effectiveness of Colostrum Use on Acceleration of Umbilical Cord Release Among the Infants at the Work area of Mekar Wangi Public Health Center Bogor City 2019
}

\author{
$1^{\text {st }} \mathrm{T}$ Indrayani \\ Lecturer in the Faculty of Health \\ Sciences \\ Universitas National Jakarta \\ Jl. Sawo Manila, RT.14/RW.3, Ps. \\ Minggu, Kec. Ps. Minggu, Kota Jakarta \\ Selatan, Daerah Khusus Ibukota Jakarta \\ 12520, Indonesia \\ triana.civitas.unas@gmail.com
}

\author{
$2^{\text {nd }} \mathrm{G}$ Dominggus \\ Midwifery Study Program \\ Faculty of Health Sciences \\ Universitas Nasional \\ Jl. Sawo Manila, RT.14/RW.3, Ps. \\ Minggu, Kec. Ps. Minggu, Kota Jakarta \\ Selatan, Daerah Khusus Ibukota Jakarta \\ 12520, Indonesia
}

\author{
$3^{\text {rd }} \mathrm{R}$ Widowati \\ Lecturer in the Faculty of Health \\ Sciences \\ Universitas National Jakarta \\ Jl. Sawo Manila, RT.14/RW.3, Ps. \\ Minggu, Kec. Ps. Minggu, Kota Jakarta \\ Selatan, Daerah Khusus Ibukota Jakarta \\ 12520, Indonesia
}

\begin{abstract}
Background: Infant mortality rate (IMR) IN Bogor year 2016-2017 is 41, 82 per 1000 life birth; it means there is no decreasing. Umbilical cord infection has become the cause pf pain and death among infants. Indonesia Health Profile 2018 states that there were 40 babies affected by neonatal tetanus; 4 babies died. Colostrum can accelerate the process of umbilical cord release through polymorph nuclear leukocytes, proteolysis enzymes and other immunological compounds. There are few bacterial colonies found on the umbilical cord when it is treated with the colostrum method. Aim: This research aims to determine the effectiveness of colostrum use to accelerate the release of the umbilical cord among infants in the working area of Mekar Wangi Public Health Center in Bogor City. Method: The study design used in this study was quasi-experimental (Quasy Experiment), using experimental and control groups. The sample in this study ware 30 people. The sampling technique used was purposive sampling Results: The results of the study were obtained using the Independent $t$ test, sig. ( 2 tailed) 0.008
\end{abstract}

Keywords - Collustrum, Umbilical, Infants

\section{INTRODUCTION}

There was approximately 220,017 infants' death occurred caused by less clean and less sterile umbilical cord treatment in Southeast Asia[1]. In 2018, Indonesian Health Profile indicated that there were 40 infants affected by neonatal tetanus of which 4 of them died. Colostrum contains polymorph nuclear leukocyte, proteolytic enzymes and immunology compound which can accelerate the process of umbilical cord release through [2]. Previous research proved that most frequently bacteria found on the tip of umbilical cord is S. Epidermidis, S. Aureus, E. Coli and Klebsiela Pneumoniae. Umbilical cord which is treated with dry and clean method is usually has more bacteria colony than umbilical cord treated using colostrum[3].

Treating umbilical cord using clean bandage which is frequently changed is suggested by World Health Organization (WHO). In addition, WHO also suggests so that research directs to the use of traditional drying substance such as breast milk or colostrum. Using breast milk or colostrum to treat umbilical cord is better than using dangerous material on umbilical cord. One of caring intervention that can be performed by midwife is by providing midwifery care to the babies in hospital out of hospital care by using colostrum. Umbilical cord treatment model using colostrum method is actually can prevent omphalitis and accelerate the umbilical cord release on newborns [4].

Colostrum has been used by KwaZulu-Natal Kenya as umbilical cord treatment method on newborns since it is proven to contain bioactive factors such as immunoglobulin, enzyme, cytokines, and cells which have effective function as anti-infection and anti-inflammation. Those various beneficial substances make the colostrum as alternative material to treat umbilical cord. Other reasons are because it is cheap, sterile, and easy to be performed by mothers and gives psychological satisfaction in treating the baby [5].

Research has been conducted to compare the effect of the colostrum application, open treatment and sterile bandage on umbilical cord treatment on 90 babies in Regional General Hospital (RSUD) of DR. M. Haulussy Ambon. At average, the release time of umbilical cord through colostrum application is less than through dry 
treatment method (8). Neonatal infection is one of the causes of infants' death. Umbilical cord infection has become constant cause of pain and death throughout the world. There was 500,017 infants died due to neonatal tetanus and 460,017 infants died due to bacterial infection annually [6]. In a controlled try-out test on 373 babies in Babol University on the effectiveness of breast milk, ethyl alcohol $96 \%$ and sulfadiazine silver reported that the umbilical cord release time using breast milk is the fastest [7]. This result is also supported by another previous research project [8]. that through the use of breast milk in releasing umbilical cord, the time taken is faster (4.03 days) compared to dry treatment (6.03 days).

\section{METHODS}

Quasi-experimental research design was employed. Observation was performed in this research for 30 days on different treatments in which there is a group which obtained experimental treatment (given treatment in the form of colostrum as umbilical cord treatment method) and control group which did not get any treatment (did not obtain any treatment, the umbilical cord was according to the fixed procedure (protap) of the public health center. The research samples who met the research criteria were 30 people, the criteria are:

a. Newborns were born normal in Public Health Center of Mekarwangi.

b. Newborns with birth weight at the range of $2500-$ 4000 gram.

c. Mothers of the baby release breast milk actively.

d. Normal newborns who do not have any physical disability and healthy as well as willing to become respondents of the research.

Purposive sampling was employed as the sampling technique. This technique allows the researcher to select. Data analysis used univariate analysis through frequency distribution and bivariate analysis through independent $\mathrm{t}$ test.

\section{RESULTS}

A. Discussion on the Length of Time of Newborns' Umbilical Cord Release using Colostrum Method

TABLE I. LENGTH OF TIME OF NEWBORNS' UMBILICAL CORD RELEASE ON COLOSTRUM GROUP

\begin{tabular}{|l|c|c|}
\hline Day & F & \% \\
\hline Day 4 & 5 & 33.3 \\
Day 5 & 4 & 26.7 \\
Day 6 & 5 & 33.3 \\
Day 7 & 1 & 6.7 \\
Day 8 & 0 & 0 \\
\hline Total & $\mathbf{1 5}$ & $\mathbf{1 0 0}$ \\
\hline
\end{tabular}

The table I above presents the analysis result on the time of newborns' umbilical cord release on intervention group or by using colostrum method on 15 respondents obtaining the intervention. Based on the table, it is obtained that the number of umbilical cord release on the day- 8 was zero $(0 \%), 5$ newborns' on the day-4 (33.3\%), 4 newborns' on the day-5 $(26.7 \%), 5$ newborns' on the day- 6 and 1 newborns' on the day- 8 (6.7\%) which experienced the longest release of umbilical cord using colostrum method.

Breast milk which is known as liquid gold is dark yellow serous fluid containing many antibody of $\operatorname{IgA}$, $\mathrm{IgG}, \operatorname{IgM}$ and has effect in protecting skin infection. It also has antibacterial and antivirus effects supporting the body immune system, increasing recovery and growth of musculoskeletal. IgA contained in colostrum is very effective in protecting baby from any infection and prevent the absorbance of foreign protein [7]. As it is easily available and used, breastmilk become noninvasive method in treating umbilical cord. Umbilical cord release becomes shorter when it uses the method of breast milk application compared to the use of antiseptic method. It has been used as home-medicine for light disease such as conjunctivitis, insect bites and stings, contact dermatitis, infected wound, infected burns, and infected blisters [9].

There are several benefits of treatment using colostrum which are cheap, easy, natural, only need short time, clean, preventing infection on newborns, safe, decrease the time of umbilical cord release and gives psychological need between the mother and her baby [10].

\section{B. Discussion on the Length of Time of Newborns' Umbilical Cord Release on Control Group}

TABLE II. LENGTH OF TIME OF NEWBORNS' UMBILICAL CORD RELEASE ON CONTROL GROUP

\begin{tabular}{|l|c|c|}
\hline Day & F & \% \\
\hline Day 4 & 2 & 13.3 \\
Day 5 & 1 & 6.7 \\
Day 6 & 5 & 33.3 \\
Day 7 & 4 & 26.7 \\
Day 8 & 3 & 20.0 \\
\hline Total & $\mathbf{1 5}$ & $\mathbf{1 0 0}$ \\
\hline
\end{tabular}

Table II shows the result analysis of the control group consisting 15 respondents. Among those respondents, 3 newborns $(20 \%)$ experienced umbilical cord release on day- 8,4 newborns $(26.7 \%)$ on day- 7,5 newborns $(33.3 \%)$ on day-6, one newborn $(6.7 \%)$ on day5 , and 2 newborns $(13.3 \%)$ on day-4, the fastest day of umbilical cord release on control group. An interview was conducted on several midwifes in Public Health Center of Mekarwangi obtaining information that open method has been used since 2010 until now. Almost all community including the newborns' born in Public Health Center of Mekarwangi has known such method. In the last several years, the umbilical cord release done using alcohol $70 \%$, povidon iodine, turmeric or others herbs was still found in several places especially in Mekarwangi area, so that the infants' death case due to tetanus were still found. Although the health workers still found difficulty to inform the community, however as time goes by, the community is finally understand regarding the umbilical cord release using more natural open treatment which is good for the newborns. The community understand how to shorten the length of time of umbilical cord release which is done without using alcohol $70 \%$, povidon iodine, turmeric or other herbs. 
Hunt in Amrullah (2017) explained that the tissue oxygenation is one of the factors affecting the process of wound healing. Enough oxygenation is really needed by this process. The better the oxygenation, the faster the wound healing will be. The oxygen level in tissue is important in forming new cells. Open wound or wound which is exposed to the air will dry faster. Oxygen has important role in forming the collagen, new capillaries, epithelium improvement, and infection control. Therefore, the cover or bandage of the umbilical cord must be chosen wisely so that the gas and air exchange is fluent. However, it is better to left open the umbilical cord so that the release of it is faster [11].

The research result shows that the treatment of umbilical cord using colostrum did not cause infection on the umbilical cord with the percentage of $100 \%$. Researcher performed follow-up for every day to check the umbilical cord infection signs such as the existence of pus, bleeding, the increase of baby temperature, bad odor, reddish around the umbilical cord base and other signs. The result of the research indicated that there was no infection happened occurred on both groups. The sign of infection on baby can be in the form of the baby look anxious and fussy, the existence of reddish around the base of the umbilical cord and belly, there is bad odor and pus released around the umbilical cord and the temperature of the baby increase.

This is in line with the previous research conductedwhich indicated that the group which used colostrum method has faster umbilical cord release than open method using alcohol $70 \%$ [12].

\section{The Comparison of the Length of Time of Umbilical Cord using Colostrum Method and Open Method on Newborns}

The bivariate analysis through independent t-test conducted from data normality test in this research using SaphiroWilk test obtained significant value for the length of time of the umbilical cord release using colostrum of 0.025 , while control group obtained 0.099 or $(p>\alpha)$. Therefore, the data is distributed normally so that the independent t-test was used. The research result obtained in table 4.5 shows the average of umbilical cord release of 5.13 or about 5 days on colostrum method, while control group took around 6.33 days. This shows that there was difference on the length of time of umbilical cord release between the colostrum method group and control group with the difference of 1.2 day or 28.8 hours.

TABLE III. THE EFFECT OF COLOSTRUM ON THE ACCELERATION OF NEWBORNS' UMBILICAL CORD RELEASE ON INTERVENTION AD CONTROL GROUPS

\begin{tabular}{|c|c|c|c|c|c|}
\hline $\begin{array}{c}\text { Types of Umbilical Cord } \\
\text { Treatment }\end{array}$ & $\mathbf{N}$ & Mean & Pvalue & $\begin{array}{c}\text { Std. } \\
\text { Deviation }\end{array}$ & $\begin{array}{c}\text { Std. } \\
\text { Error } \\
\text { Mean }\end{array}$ \\
\hline Colostrum & 15 & 5.13 & 0.008 & 0.994 & 0.255 \\
\hline Open & 15 & 6.33 & & 1.290 & 0.333 \\
\hline
\end{tabular}

It was proven through this research that there was significant relationship $(\mathrm{pv}=0.008)$ between the two methods with the length of time of the umbilical cord. It means that $\mathrm{pv}=0.008<0.05$, thus the hypothesis of the research is accepted since there was effect of the colostrum method in the umbilical cord treatment on the length of time of the release on newborns.

Blood supply from the mothers will be released during the cut of the umbilical cord. After the umbilical cord is cut and binded, it needs to be treated. The purpose of the umbilical cord treatment is to keep the umbilical cord dry and prevented from infection. It needs to be treated to prevent the umbilical cord to become the media of pathogen microorganism breeding. Good and correct umbilical cord treatment will affect positively in which the umbilical cord will be released on the day- 5 to 7 without any.

Umbilical cord which is opened freely and exposed to the air will make it becomes dry faster in addition to the provision of colostrum which is a natural substance to fasten the drying. Umbilical cord treatment basically needs to be clean, sterile, natural, moist, dry and in accordance with the method so that it will avoid the occurrence of infection on the umbilical cord. Furthermore, the use of colostrum to treat umbilical cord which can avoid infection is also due to the anti- inflammation and anti-bacteria substance so that the umbilical cord which smeared with colostrum will be protected from germs.

Colostrum and open method have the same principle which is uncovered. However, there is actually differences between the two treatments. Allam, et. Al., (2015) conducted a research resulting that $80 \%$ of the experimental group's length of time of the umbilical cord release was at the average of 4-5 days and only $20 \%$ of the control group took 5-6 days for the release of the umbilical cord. Furthermore, there was 1 newborn on the control group who experienced the release on the day-5 while the other $75 \%$ of the newborns experienced release of their umbilical cord on the day-7 [13]. Health workers and mothers need to know that colostrum method can also be used to fasten the umbilical cord release on newborns. In addition to decrease the possibility of infection, it also saves more money because infection can cause to cost much money for the medication [7].

\section{CONCLUSION}

There was effect of colostrum method on the length of time of umbilical cord release. It is expected that the institution can facilitate the development of research by adding book source and cooperate with relevant institution. Future researcher is expected to develop the 
research by adding the number of samples so that it can get maximal result.

\section{ACKNOWLEDGMENTS}

The researcher would like to express the deepest appreciation to the Faculty of Health Sciences UNAS, as well as the Midwifery Study Program of the Institute for Research and Community Service UNAS for the supports so that this research could be carried out well.

\section{REFERENCES}

[1] R. Damanik, "Hubungan Perawatan Tali Pusat dengan Kejadian Infeksi pada Bayi Baru Lahir di RSUD Dr. Pirngadi Medan,” J. Keperawatan Prior., vol. 2, no. 2, pp. 51-60, 2019.

[2] S. S. Hermanses, "METODE APLIKASI COLOSTRUM MERUPAKAN PREKUSOR BAGI PERCEPATAN PENGERINGAN TALI PUSAT PADA BAYI BARU LAHIR.," Glob. Heal. Sci., vol. 4, no. 2, pp. 125-134, 2018.

[3] W. Putri, D., Yuliani, W., \& Widdefrita, "Perbandinagan Penggunaan Topikal ASI dengan Perawatan Kering Terhadap Lama Pelepasan Tali Pusat Bayi," AFIYAH, vol. 4, no. 2, 2018.

[4] L. OCTAVIANA, "PENGARUH PERAWATAN TALI PUSAT MENGGUNAKAN METODE TOPIKAL ASI DAN KASA KERING TERHADAP WAKTU PELEPASAN TALI PUSAT BAYI BARU LAHIR PERSALINAN POST SC DI RSU DELIMA MEDAN TAHUN 2018," NSTITUT Kesehat. Helv., 2018.

[5] S. Supriyanik, F., \& Handayani, "erbedaan Perawatan Tali Pusat Dengan Menggunakan Asi Dan Dengan Kassa Kering Terhadap Lama Pelepasan Tali Pusat Bayi Baru Lahir Di Bps Endang Purwati Yogyakarta.," J. Kesehat. Samodra Ilmu, vol. 3, no. 2, 2011.

[6] M. K. Sodikin, Buku Saku Perawatan Tali Pusat. .

[7] D. Astari, R. Y., \& Nurazizah, "Perbandingan Metode Kolostrum dan Metode Terbuka Terhadap Lama Pelepasan Tali Pusat pada Bayi Baru Lahir.," Faletehan Heal. J., vol. 3, no. 6, pp. 91-98, 2019.

[8] H. I. Dewi, D. Y. R., \& Tondong, "Pengaruh Pemberian Topikal ASI terhadap Pelepasan Tali Pusat di BPM Anatapura dan BPM Setia," J. Bidan Cerdas, vol. 1, no. 1, pp. 44-50, 2018.

[9] M. Elsobky, F., Emam, A., Abd Elmenim, S., \& Shahin, "Effect of Topical Application of Mother Milk on Umbilical Cord Stump Separation Time Compared To Ethanol in Healthy Newborn.," Int. J. Nov. Res. Healthc. Nurs., vol. 4, no. 1, pp. 1-11, 2017.

[10] L. Aghamohammadi, A., Zafari, M., \& Moslemi, "Comparing the effect of topical application of human milk and dry cord care on umbilical cord separation time in healthy newborn infants," Iran. J. Pediatr., vol. 2, no. 22, p. 158, 2012.

[11] A. A. Amrullah, "Gambaran Risiko Infeksi Nosokomial pada Perawat di Ruang Rawat Inap RSUD Haji Makassar Tahun 2016.," Univ. Islam Negeri Alauddin Makassar., 2017.

[12] N. Golshan, M., \& Hossein, "Impact of ethanol, dry care and human milk on the time for umbilical cord separation," J Pak Med Assoc, vol. 63, no. 9, pp. 1117-1119, 2013.

[13] I. Maharani, I. S., \& Yudianti, "PRAKTIK PEMBERIAN ASI DAN WAKTU PELEPASAN TALI PUSAT BAYI BARU LAHIR.," J. Ilm. Kebidanan (Scientific J. Midwifery), vol. 4, no. 2, pp. 125-134, 2018. 